\title{
A study of diazonium couplings with aromatic nucleophiles both in solution and on a polymer
} surface.

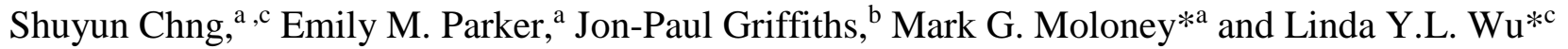

a Department of Chemistry, Chemistry Research Laboratory, The University of Oxford, Mansfield Road, Oxford. OX1 3TA.

b Oxford Advanced Surfaces Ltd, Begbroke Centre for Innovation and Enterprise, Oxford University Begbroke Science Park, Sandy Lane, Yarnton, OX5 1PF.

c Singapore Institute of Manufacturing Technology, Level 10, Innovis \& Kinesis, 2 Fusionopolis Way, Singapore 138634.

Email: mark.moloney@chem.oxa.c.uk, ylwu@SIMTech.a-star.edu.sg

\begin{abstract}
Diazonium coupling is a technique finding wider application to materials and biological science, for hybridization and linking processes, and for the construction of responsive surface functionality. For this reason, detailed examination of solution and surface processes was warranted, and results of such a study are reported here. The modification of polystyrene surfaces was examined as a model, and the process compared to a solution mimic using $N, N$ dimethylaniline. It was confirmed that solution and solid surface reactions proceed in a similar manner in terms of the chemical functionality generated, but with lower chemical efficiency and reaction times slower for the latter, in a reaction which was $\mathrm{pH}$ dependent. The solution process was shown to give only the trans-azo para- coupled products. Whilst there are clear similarities between the solution and surface chemistry, the efficiency of coupling at a surface is not necessarily replicated in the chemical yield of the mimicking solution processes, but nonetheless provides an alternative to other Click-type surface modifications. It should not be assumed that such couplings occur with quantitative efficiency at the surface.
\end{abstract}

\section{Introduction}


The introduction of chromophoric groups onto polymers and biomaterials has been developed[1-3] and the azo-function (R-N=N-R') has become important in that regard,[4, 5] principally as a result of its ease of introduction and intense colour.[6] Because of the ease of formation of the azofunction, especially from aryl diazonium salts, it has also been used as a linking group[7] to couple polymers,[8] biomacromolecules and nanoparticles to surfaces[4], to introduce light switching,[9, 10] mechanical motion[11] and nanoelectronic properties,[12, 13] and for the control of wettability and swelling behaviour.[14-17] Moreover, photomediated trans- to cis- interconversion of the azo group is well known[18, 19] and has been used in the development in a wealth of photo-responsive materials, including reversible gel-sol systems,[20] polymers,[19, 21] molecular switches,[22, 23] and modified proteins.[24-27] Our interest in this area has been the use of the azo-link, formed by diazonium coupling with an activated nucleophilic surface,[28-31] as a key coupling component to give modified materials with new chemical surface functionality. While these materials may be characterised using combustion analysis, XPS analysis, IR and UV/visible spectroscopy, none of these techniques gives direct chemical evidence of the newly introduced azo-function, and of importance was whether the surface coupling reaction proceeds in a similar manner to its solution counterpart both in terms of (a) identity; and (b) efficiency of formation of the linking group. Therefore, we investigated coupling behaviour in solution using suitable model substrates and compared this to the modified surfaces in some detail, and report that work here.

\section{Results and Discussion}

\section{Polystyrene materials}

Functional polystyrenes were prepared using our reported two-step modification process (Scheme 1).[32, 33] First, polystyrene (crosslinked, XAD-4) was reacted with an anilineterminated carbene, by heating a solid dispersion of diaryl diazo-compound $\mathbf{1}$ on the polystyrene. The resulting modified polystyrene 2 , with a surface loading density of $0.18 \mathrm{mmolg}^{-1}$ [32] and now activated to electrophilic substitution at the surface, was then further reacted with a range of diazonium salts 3a-h, to give azo-functional polystyrenes $\mathbf{4 a - h}$. Alkaline hydrolysis of phosphate 
diester $\mathbf{4 d}$ gave phosphate monoester $\mathbf{4 i}$. Overall, this gave a range of surface-modified materials terminated with hexyl, hydroxyl, glycol, phosphonate diester, carboxylate and phosphonate functional groups.

The UV-visible behaviour of azobenzene systems in solution has been investigated in detail; the wavelengths and intensity of the $\pi \rightarrow \pi^{*}$ and $n \rightarrow \pi^{*}$ absorptions found to depend on whether azobenzene, aminoazobenzene, and pseudostilbene types are present.[34] trans-Azobenzene has two peaks of interest at $320 \mathrm{~nm}$ and $450 \mathrm{~nm}$, ascribed to the $\pi \rightarrow \pi^{*}$ and $\mathrm{n} \rightarrow \pi^{*}$ transitions of the azo functionality, respectively.[18] The $n \rightarrow \pi^{*}$ transition, however, is forbidden, so has a very small extinction coefficient, often resulting in the absence of its associated signal.[35] Since the coupling process in Scheme 1 involves an electron-donating amine component, a significant bathochromic shift in the $\pi \rightarrow \pi^{*}$ transition was expected. Moreover, while the trans-azo geometry is the thermally stable one, the cis- form can be accessed by exposure to UV light, resulting in a change in the UV spectrum: the $\pi \rightarrow \pi^{*}$ transition undergoes a hypsochromic shift to a lower wavelength (from 320 to $\sim 270 \mathrm{~nm}$ ), but the $\mathrm{n} \rightarrow \pi^{*}$ increases by only a small amount.[17, 18, 36] However, while reports of UV analysis of azobenzene-modified materials are less common, and in any case have typically been achieved in solution,[17, 36] a solid cellulose surface-modified with azobenzene has been used to control wettability and exhibited similar trends to those observed in solution.[37] 


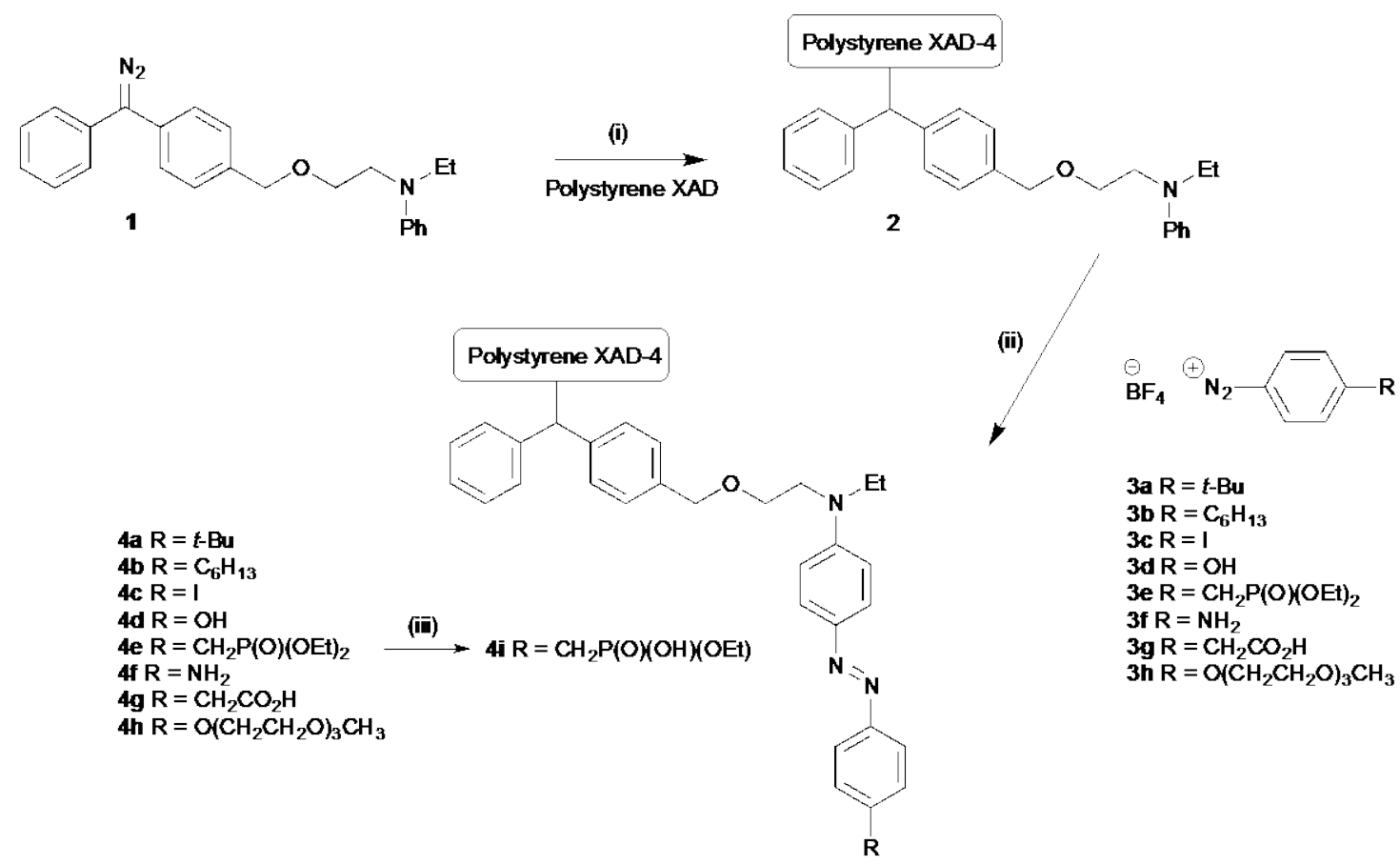

Scheme 1: Preparation of polystyrene materials. Conditions: (i) heat to $120{ }^{\circ} \mathrm{C}$; (ii) diazonium salt solution in EtOH, 18 hrs, $0-5$ ${ }^{\circ} \mathrm{C}$; (iii) $5 \%$ aq. $\mathrm{NaOH}, 18$ hrs.

All of the materials 4a-i are highly coloured (either red-orange or purple), with the exception of amine-terminated $\mathbf{4 f}$ (yellow) (Table 1). Diffuse reflectance UV-Vis spectroscopic analysis of a selection of the materials showed a significant change in chromophore after surface modification (Figure 1 and Table 1). Figure 1a shows the UV absorbance spectra of the unmodified XAD-4 beads, as-received but after washing, along with the diazo modified aniline material 2. Both materials exhibit peaks at $287 \mathrm{~nm}$, as a result of the $\pi \rightarrow \pi^{*}$ transition for the aromatic rings of the polystyrene substrate. Aniline $\mathbf{2}$, however, additionally shows a broader absorbance along with a shoulder peak at $346 \mathrm{~nm}$, resulting from a bathochromic shift due to the donation of the aniline $\mathrm{N}$ lone pair in the surface groups, and providing clear evidence for the surface modification. Figure 1b shows the background-adjusted UV spectra obtained from a selection of the coupled materials 4b, d, e, h, i. This data clearly indicates that the surface modification has made a significant chromophoric change to the materials, with materials all having a broad absorbance at wavelengths in the range of 410-650 nm, consistent with their observed colour. Materials $\mathbf{4 b} \mathbf{b} \mathbf{d}$, $\mathbf{e}$ and $\mathbf{h}$ have two broad peaks, with a lower peak at 410-460 nm and a second peak at 497-576 nm. The first peak results from the $\pi \rightarrow \pi^{*}$ transition of the azo bond, consistent with a trans-azo geometry.[37] 
The second and higher wavelength peak is due to the protonation at either of the azo or amine sites, producing the azonium or ammonium salts, respectively.[38] An ammonium cation is known to exhibit a hypsochromic shift due to the loss of the electron-donating ability of the nitrogen lonepair, while protonation at the azo site results in a significant bathochromic shift to the region of $\sim 500 \mathrm{~nm}$. Since the diazonium coupling reaction used for the polymer modification was conducted under acidic conditions, such protonation is plausible and to be expected. By contrast, phosphonate monoester terminated $\mathbf{4 i}$ has only one peak at $453 \mathrm{~nm}$; it was obtained by hydrolysis of $\mathbf{4 e}$ in aqueous sodium hydroxide, and therefore the protonated form is not present; for this reason, the modified material is different in colour (yellow) compared to all of the other materials. This data all supports the identity of the newly introduced coupling group as being an azo- function.

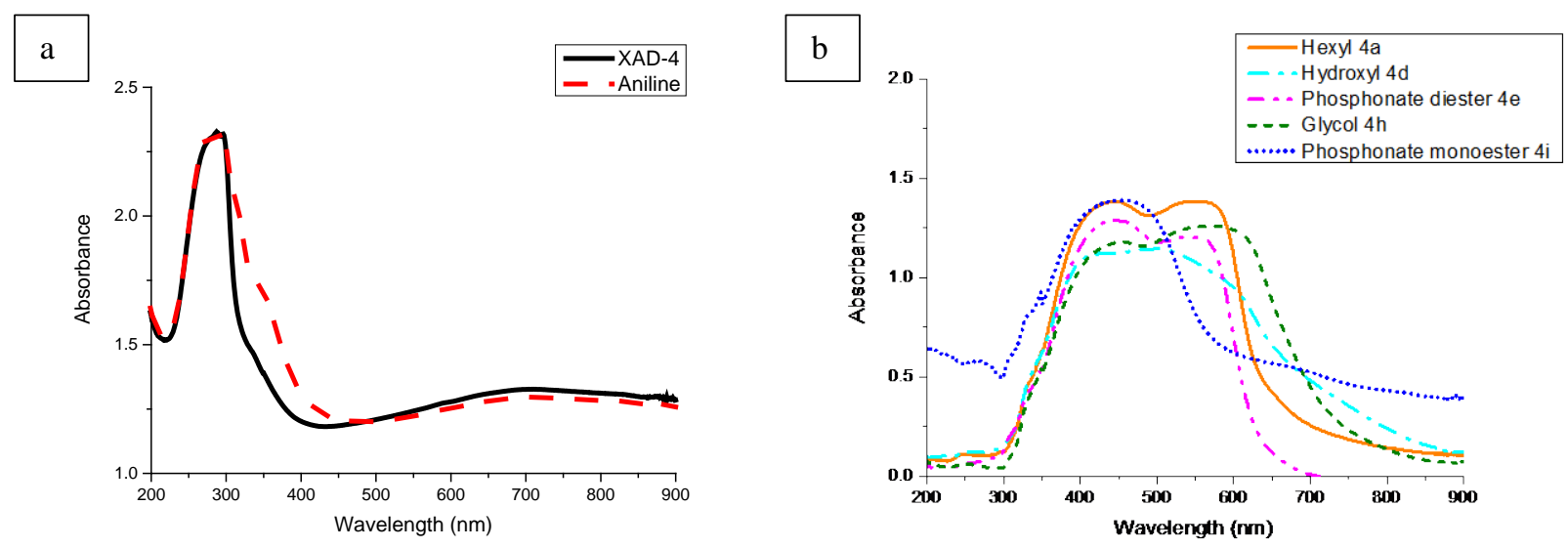

Figure 1: UV spectra of (a) uncoupled polystyrene XAD-4 1 and aniline 2; and (b) coupled materials 4a, d, e, h. Absorbance has been corrected using aniline terminated material 2 as a reference.

\begin{tabular}{|cccc|}
\hline Material & & Peak 1 & Peak 2 \\
(R) & Appearance & $(\mathbf{n m})$ & $(\mathbf{n m})$ \\
& & Absorbance & Absorbance \\
\hline 4b & & 446 & 540 \\
$\left(\mathrm{C}_{6} \mathrm{H}_{13}\right)$ & & 1.38 & 1.38 \\
\hline
\end{tabular}




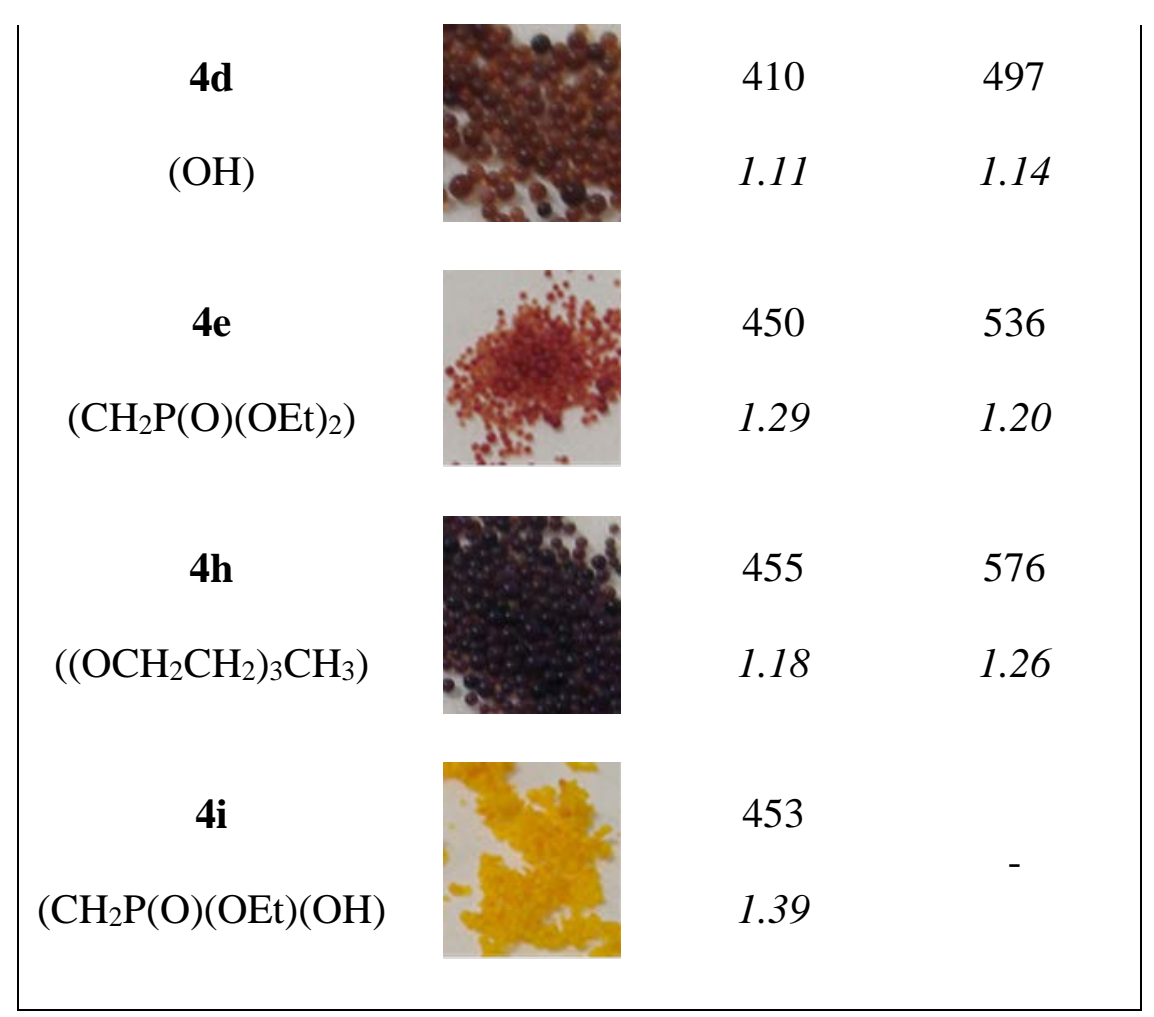

Table 1: Peaks observed by diffuse UV-Vis spectroscopic analysis of coupled materials. Absorbance has been corrected using aniline terminated material 2 as a reference. Photographs reproduced from Ref.[32] with permission from the Centre National de la Recherche Scientifique (CNRS) and The Royal Society of Chemistry.

The efficiency of the coupling was estimated by comparison of surface loading of the modified polymers (as measured from nitrogen combustion data) relative to that of the starting material 2 (Table 2).[32] Coupling efficiency was typically in the range 28-67\%; the value for iodo modified polymer 4c was significantly higher than these, and this may be due to activation of the iodoaryl unit towards further diazonium coupling (see below).

\section{Solution Coupling Reactions}

To further understand these surface reactions, a solution study was conducted using $N, N$ dimethylaniline as a model substrate, along with a similar selection of diazonium salts (Scheme 2). This allowed for spectroscopic confirmation of the identity of the coupling products in solution, which was otherwise not possible for the modified polystyrene materials. Since the effect of $\mathrm{pH}$ on the diazonium coupling reaction is known in solution,[39-41] it was similarly examined here. The diazonium salts were synthesised in ethanol at $-5-0{ }^{\circ} \mathrm{C}$ using isopentyl nitrite, along with the relevant aniline 6a-f and tetrafluoroboric acid (Scheme 2), using the literature approach.[42] The colourimetric H-acid test[43] was used to confirm the formation of the diazonium salts in step (i) of 
Scheme 2. During the coupling reaction, a significant colour developed on addition of the reagents, which had stabilised by completion of reaction (typically $1 \mathrm{~h}$ ).

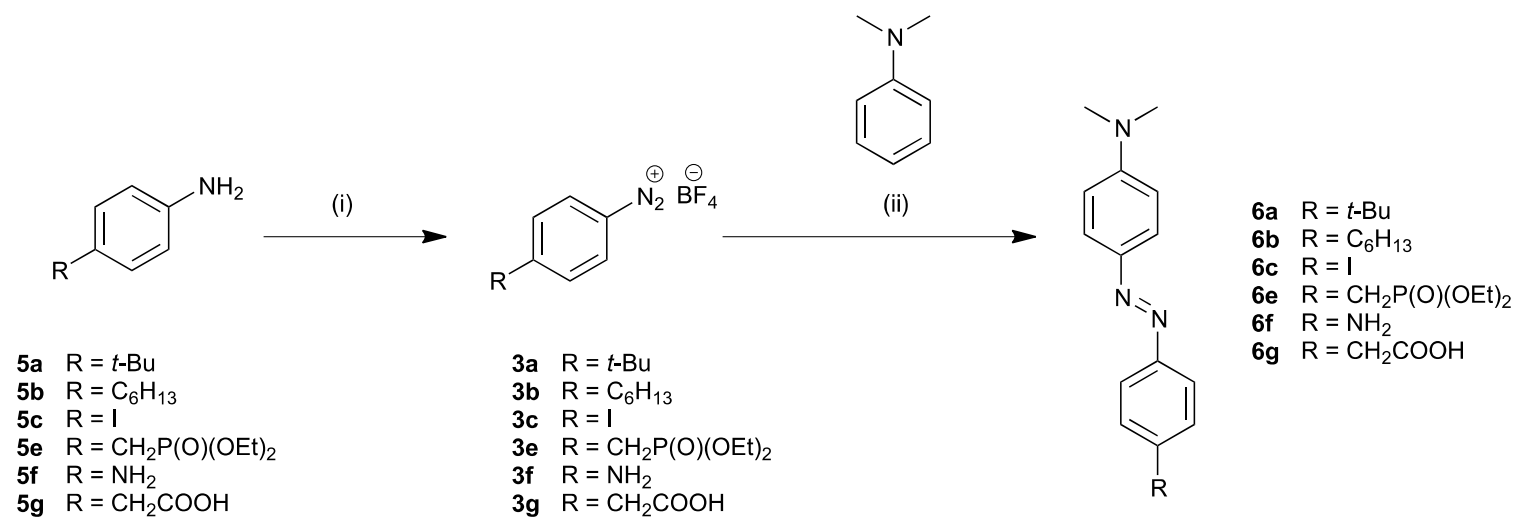

Scheme 2: Solution diazonium coupling. Conditions: i) isopentyl nitrite, $\mathrm{HBF}_{4}, \mathrm{EtOH},-5$ C; ii) Procedure A: $3 a-c$, e-g were added then the mixture warmed to room temperature and stirred; Procedure B: NaOAc then 3a-c, e-g were added and the mixture stirred at room temperature.

The diazonium salts were reacted with $N, N$-dimethylaniline using two protocols. For the first (Method A), N,N-dimethylaniline was added directly and the mixture warmed to room temperature. For the second (Method B), sodium acetate was initially used to adjust the $\mathrm{pH}$ of the diazonium salt mixture, followed by the addition of dimethylaniline and warming to room temperature. The reactions were followed by TLC analysis; the reactions times were variable and complete consumption of $N, N$-dimethylaniline was rarely observed (Table 2). Unreacted amines 5a-c, 5e-g from the alkyl, acid, phosphonate diester and iodo cases were observed, although no unreacted $p$-phenylenediamine $\mathbf{5 f}$ was recovered. In one case, 1,3-bis(4-iodophenyl)triaz-1-ene 7 was detected by mass spectrometric and NMR spectroscopic analysis of the crude mixture generated from Method B, as a result of the reaction of the diazonium salt 3c with starting 4iodoaniline 5c. This product was not observed when the reaction was done in acidic medium (Method A). It is known that use of mildly basic conditions can also result in $N$-coupling when there are primary anilines present,[4] as there would be if unreacted 4-iodoaniline was present. The difference in the coupling yields are likely to result both from variation in the efficiency of the diazonium salt formation, and the diazonium coupling process itself. 


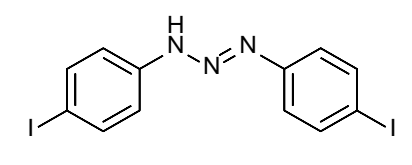

7

\begin{tabular}{|c|c|c|c|c|c|c|c|c|}
\hline \multirow[b]{2}{*}{ Product } & \multirow[b]{2}{*}{$\mathbf{R}$} & \multicolumn{2}{|c|}{ Method A } & \multicolumn{2}{|c|}{ Method B } & \multicolumn{3}{|c|}{ Materials Surface Loading ${ }^{b}$} \\
\hline & & $\begin{array}{c}\text { Reaction } \\
\text { time } \\
\text { (hr) }\end{array}$ & $\begin{array}{l}\text { Yield } \\
(\%)\end{array}$ & $\begin{array}{c}\text { Reaction } \\
\text { time } \\
\text { (hr) }\end{array}$ & $\begin{array}{l}\text { Yield } \\
(\%)\end{array}$ & Polymer & $\begin{array}{c}\text { mmol of } \\
\text { surface } \\
\text { modification } \\
\text { /g of } \\
\text { polymer }\end{array}$ & $\begin{array}{c}\text { Coupling } \\
\text { Efficiency(\%) }\end{array}$ \\
\hline 6a & $t-\mathrm{Bu}$ & 18 & 72 & 4 & 91 & $4 a$ & 0.062 & 34 \\
\hline 6b & $\mathrm{C}_{6} \mathrm{H}_{13}$ & 18 & 20 & 20 & 73 & 4b & 0.067 & 37 \\
\hline 6c & $\mathrm{I}$ & 0.5 & 64 & 0.5 & 57 & 4c & 0.357 & 198 \\
\hline $6 e$ & $\mathrm{CH}_{2} \mathrm{P}(\mathrm{O})(\mathrm{OEt})_{2}$ & 1 & 96 & 1 & 46 & $4 e$ & 0.121 & 67 \\
\hline 6f & $\mathrm{NH}_{2}$ & 18 & 0 & 18 & $12^{\mathrm{a}}$ & $4 f$ & 0.046 & 26 \\
\hline $6 g$ & $\mathrm{CH}_{2} \mathrm{COOH}$ & 20 & 95 & 18 & 34 & $4 g$ & 0.052 & 28 \\
\hline
\end{tabular}

Table 2. Results of solution diazonium coupling. a) Yield calculated from NMR data; b) Determined from combustion analysis of the analogous polystyrene based materials - see reference [32]. Coupling efficiency determined by comparison of surface loading relative to that of the starting material 2 (with a surface loading density of $0.18 \mathrm{mmolg}^{-}$ ${ }^{1}$.[32]

The introduction of sodium acetate to control the $\mathrm{pH}$ of the reactions (Method $\mathrm{B}$ ) gave mixed results; while yields of reactions for the hexyl $\mathbf{6 b}$, amine $\mathbf{6 f}$ and $t$-butyl $\mathbf{6 a}$ systems were increased under these conditions, the acid $\mathbf{6 g}$, phosphonate $\mathbf{6 e}$ and iodo $\mathbf{6 i}$ salts reactions proceeded with lower yields. It is notable that that the acid and amine system $\mathbf{6 f}$ and $\mathbf{6 g}$ were difficult to purify after reaction as a result of their polarity. Overall, these data point to increased reactivity with electron releasing groups (formation of $\mathbf{6 a , b}$ ) and lower reactivity with electron withdrawing groups (formation of $\mathbf{6 c , e , g ) . ~ T h e ~ c a s e ~ o f ~} \mathbf{6 f}$ is different, and suggests that reaction under acidic conditions is poor, and best achieved under basic conditions when the amine groups are not protonated. It is apparent that an efficient coupling in the solution phase (that is, high chemical yield) should not be assumed to imply an efficient material surface coupling (that is, high surface loading) and or efficient coupling (Table 2). 
NMR spectroscopic analysis of all the products 6a-c, e-g revealed that only the para coupled products were produced; there was no evidence of reaction at the ortho position. Thus, in the spectra for each product, four apparent doublets were observed in the range of 6.7-7.9 ppm, corresponding to the two para-substituted systems, exemplified for t-butyl 6a (Figure 2). Furthermore, the symmetry of this NMR spectrum also confirms the formation of the trans-azo isomers, and there is no evidence for the cis form. These azobenzene compounds are significantly coloured in solution and absorb light strongly in the region 200-800 nm (Table 3). The electrondonating dimethyl amine group induces a significant bathochromic shift, compared to unsubstituted azobenzene, so that the $\pi \rightarrow \pi^{*}$ azo transition ranges from 410 to $425 \mathrm{~nm}$. Iodo-terminated $\mathbf{6 c}$ has the largest shift as a result of the push-pull effect of the electron donating and withdrawing groups at either end of the molecule, and which increases the wavelength of adsorption.[38, 44] The weak $\mathrm{n} \rightarrow \pi^{*}$ transition was not observed, and in any case may be obscured by the broad peak of the $\pi \rightarrow \pi^{*}$ azo transition. The compounds also absorbed at $250-285 \mathrm{~nm}$, which is due to the $\pi \rightarrow \pi^{*}$ benzene transition.

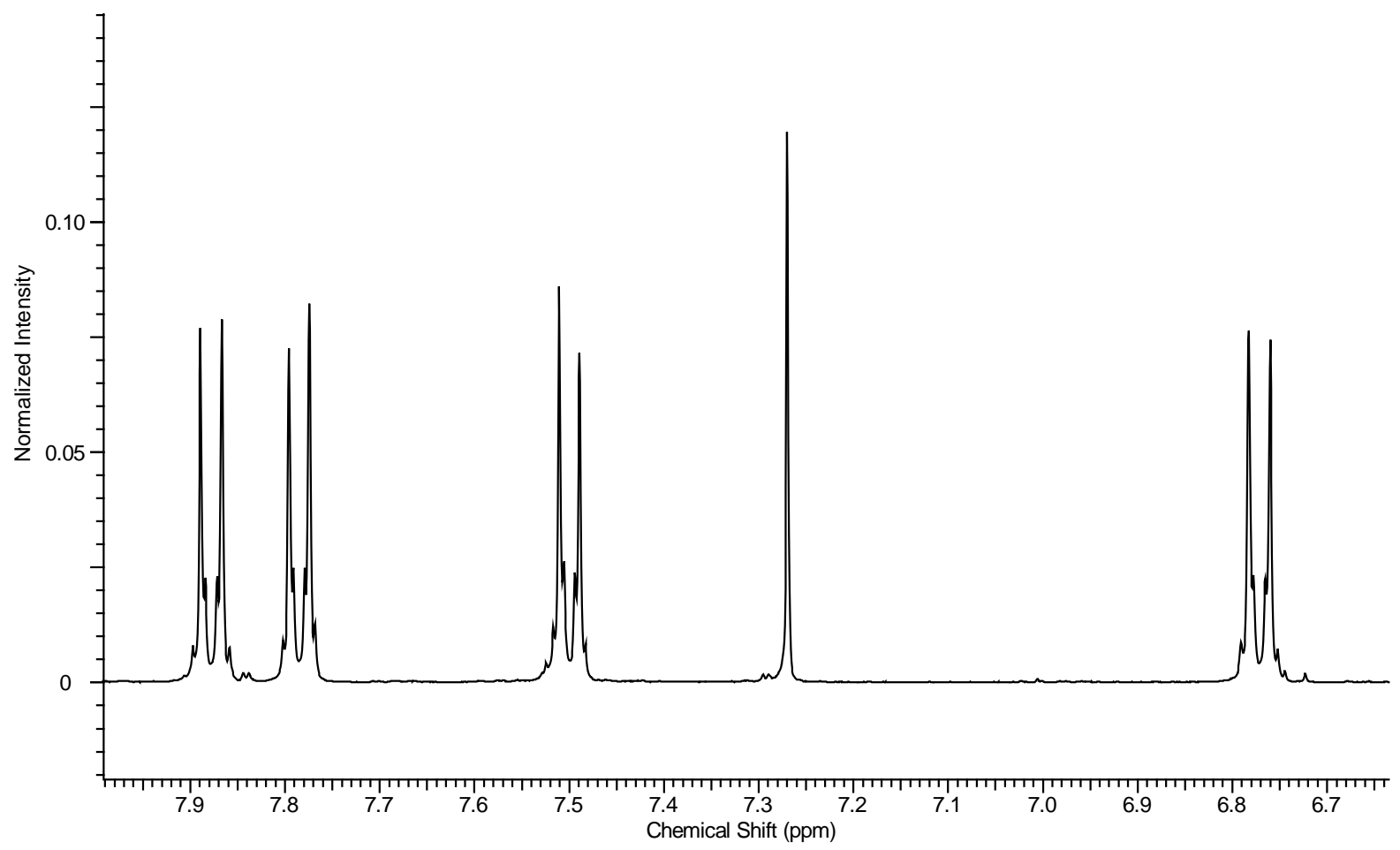

Figure 2: NMR Spectrum of the aromatic region for exemplified for $t$-butyl 6 a 


\begin{tabular}{|c|c|c|c|c|c|}
\hline \multirow{2}{*}{ Product } & \multirow{2}{*}{$\mathbf{R}$} & \multicolumn{2}{|c|}{$\pi \rightarrow \pi^{*}$ benzene } & \multicolumn{2}{c|}{$\pi \rightarrow \pi^{*}$ azobenzene } \\
\cline { 3 - 6 } & & $\begin{array}{c}\lambda_{\max } \\
(\mathrm{nm})\end{array}$ & $\begin{array}{c}\text { Extinction } \\
\text { coefficient } \\
\left(\mathrm{mol}^{-1} \mathrm{dm}^{3} \mathrm{~cm}^{-1}\right)\end{array}$ & $\begin{array}{c}\lambda_{\max } \\
(\mathrm{nm})\end{array}$ & $\begin{array}{c}\text { Extinction } \\
\text { coefficient } \\
\left(\mathrm{mol}^{-1} \mathrm{dm}^{3} \mathrm{~cm}^{-1}\right)\end{array}$ \\
\hline $\mathbf{6 a}$ & $\mathrm{t}-\mathrm{Bu}$ & 285 & 3200 & 412 & 5040 \\
\hline $\mathbf{6 b}$ & $\mathrm{C}_{6} \mathrm{H}_{13}$ & 255 & 11000 & 410 & 24000 \\
\hline $\mathbf{6 c}$ & $\mathrm{I}$ & 273 & 2400 & 425 & 3840 \\
\hline $\mathbf{6 e}$ & $\mathrm{CH}_{2} \mathrm{P}(\mathrm{O})(\mathrm{OEt})_{2}$ & 263 & 10000 & 416 & 25000 \\
\hline $\mathbf{6 f}$ & $\mathrm{NH}$ & 250 & 4700 & 413 & 5980 \\
\hline $\mathbf{6 g}$ & $\mathrm{CH}_{2} \mathrm{COOH}$ & 262 & 4800 & 415 & 8500 \\
\hline
\end{tabular}

Table 3: UV-vis spectroscopic analysis of azo- coupled products 6.

Of further interest was an assessment of this coupling reaction with a range of electron-rich substrates; benzenes 8a-c, with $\mathrm{NMe}_{2}$, $\mathrm{OMe}$ and $\mathrm{OH}$ substitution respectively, were chosen. These were coupled with a diazonium salts 10a-e, prepared from their respective amines 9a-e using either of two conditions (Methods A or B, Scheme 3), and the outcomes are indicated in Table 3. Of interest was that the azo-coupling, at least for dimethylaniline, generally gave better yields with condition A, using $\mathrm{NaNO}_{2}$ with $\mathrm{HCl}$ in THF and $\mathrm{H}_{2} \mathrm{O}$, compared to condition $\mathrm{B}$, using isopentyl nitrite with $\mathrm{HBF}_{4}$ in EtOH, and this could be due to the counter-ion of the diazonium salt, since the non-nucleophilic tetrafluoroborate $\left(\mathrm{BF}_{4}^{-}\right)$anion is known to enhance the stability of the diazonium salt compared to nucleophilic chloride $\left(\mathrm{Cl}^{-}\right)$anion.[45, 46] Importantly, the azo-coupling reactions were found to be $\mathrm{pH}$ dependent: thus, the addition of 1 equivalent of $\mathrm{NaOAc}$ to reduce the acidity of the reaction mixture to about pH 4 - 5 could result in $47-65 \%$ increase in yields. An additional 1 equivalent of $\mathrm{NaOAc}$ also improved yields further by about $10-18 \%$. It would appear that by 
controlling the $\mathrm{pH}$ of the mixture to about $\mathrm{pH} 4-5$, protonation of the substrate, which could inhibit the coupling reaction, is avoided.
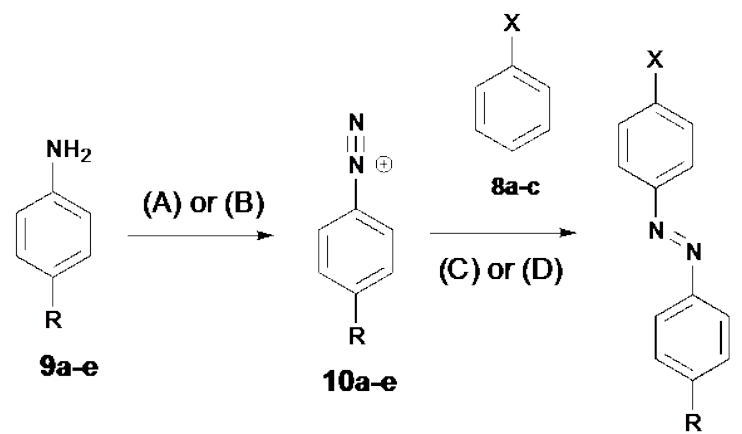

11a-f $X=-\mathrm{NMe}_{2}$

12a-f $X=-O H$

13a-f $X=-O M e$

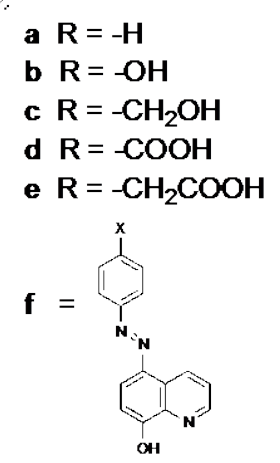

Scheme 2

Scheme 3. Azo coupling reactions. Conditions: (A): $\mathrm{NaNO}_{2}, \mathrm{HCl}, \mathrm{THF}, \mathrm{H}_{2} \mathrm{O}$; (B): Isopentyl nitrite, $\mathrm{HBF}_{4}$, EtOH; (C): without $\mathrm{NaOAc}$ (D), with NaOAc.

By contrast, however, not all diazonium salts reacted cleanly with phenol or dimethylaniline to give the desired products. Complex mixtures resulted from the coupling with diazonium salts 10b,e, and although it was not possible to purify and isolate the products $\mathbf{1 1 b}, \mathbf{e}$ and $\mathbf{1 2 b}, \mathbf{e}$, these products were detected in the reaction mixtures with their molecular ion (as $[\mathrm{M}+\mathrm{H}]^{+}$or $\left.[\mathrm{M}-\mathrm{H}]^{-}\right)$ being the base peak. Importantly, there was little or no reaction of the diazonium salts with anisole (entries 29-34). This is consistent with reports that such neutral species are not sufficiently nucleophilic for the azo coupling reaction to take place,[4] and that a more electrophilic diazonium salt is required.[46-49] Overall, while diazonium couplings with good efficiency may be expected for phenol and dimethylaniline systems, but less so for anisole type systems, in solution, the latter on a modified surface show much better reactivity.[30, 50]

\begin{tabular}{|c|c|c|c|c|c|}
\hline Entry & $\mathbf{X}$ & $\mathbf{R}$ & Product & Conditions & Yield / \% \\
\hline $\mathbf{1}$ & $-\mathrm{NMe}_{2}$ & $-\mathrm{H}$ & $\mathbf{1 1 a}$ & $(\mathrm{A})+(\mathrm{C})$ & 40 \\
\hline $\mathbf{2}$ & $-\mathrm{NMe}_{2}$ & $-\mathrm{H}$ & $\mathbf{1 1 a}$ & $(\mathrm{A})+(\mathrm{D})^{\mathrm{a}}$ & 98 \\
\hline $\mathbf{3}$ & $-\mathrm{NMe}_{2}$ & $-\mathrm{H}$ & $\mathbf{1 1 a}$ & $(\mathrm{B})+(\mathrm{C})$ & 20 \\
\hline $\mathbf{4}$ & $-\mathrm{NMe}_{2}$ & $-\mathrm{H}$ & $\mathbf{1 1 a}$ & $(\mathrm{B})+(\mathrm{D})^{\mathrm{a}}$ & 67 \\
\hline $\mathbf{5}$ & $-\mathrm{NMe}_{2}$ & $-\mathrm{OH}$ & $\mathbf{1 1 b}$ & $(\mathrm{A})+(\mathrm{D})^{\mathrm{a}}$ & Complex mixture $^{\mathrm{c}}$ \\
\hline $\mathbf{6}$ & $-\mathrm{NMe}_{2}$ & $-\mathrm{CH}_{2} \mathrm{OH}$ & $\mathbf{1 1 c}$ & $(\mathrm{A})+(\mathrm{D})^{\mathrm{a}}$ & 96 \\
\hline $\mathbf{7}$ & $-\mathrm{NMe}_{2}$ & $-\mathrm{COOH}$ & $\mathbf{1 1 d}$ & $(\mathrm{A})+(\mathrm{D})^{\mathrm{a}}$ & 97 \\
\hline $\mathbf{8}$ & $-\mathrm{NMe}_{2}$ & $-\mathrm{CH}_{2} \mathrm{COOH}$ & $\mathbf{1 1 e}$ & $(\mathrm{A})+(\mathrm{C})$ & Complex mixture $^{\mathrm{c}}$ \\
\hline $\mathbf{9}$ & $-\mathrm{NMe}_{2}$ & $-\mathrm{CH}_{2} \mathrm{COOH}$ & $\mathbf{1 1 e}$ & $(\mathrm{A})+(\mathrm{D})^{\mathrm{a}}$ & Complex mixture $^{\mathrm{c}}$ \\
\hline
\end{tabular}




\begin{tabular}{|c|c|c|c|c|c|}
\hline 10 & $-\mathrm{NMe}_{2}$ & -8-hydroxyquinoline & 11f & (A) & Complex mixture \\
\hline 11 & $-\mathrm{NMe}_{2}$ & -8-hydroxyquinoline & 11f & $(\mathrm{A})+(\mathrm{D})^{\mathrm{a}}$ & Complex mixture \\
\hline 12 & $-\mathrm{OH}$ & $-\mathrm{H}$ & $12 a$ & $(\mathrm{~A})+(\mathrm{C})$ & 34 \\
\hline 13 & $-\mathrm{OH}$ & $-\mathrm{H}$ & $12 a$ & $(\mathrm{~A})+(\mathrm{D})^{\mathrm{a}}$ & 82 \\
\hline 14 & $-\mathrm{OH}$ & $-\mathrm{H}$ & $12 a$ & $(\mathrm{~A})+(\mathrm{D})^{\mathrm{b}}$ & 95 \\
\hline 15 & $-\mathrm{OH}$ & $-\mathrm{OH}$ & 12b & $(\mathrm{A})+(\mathrm{C})$ & Complex mixture $^{\mathrm{C}}$ \\
\hline 16 & $-\mathrm{OH}$ & $-\mathrm{OH}$ & 12b & $(\mathrm{A})+(\mathrm{D})^{\mathrm{a}}$ & Complex mixture $^{\mathrm{C}}$ \\
\hline 17 & $-\mathrm{OH}$ & $-\mathrm{CH}_{2} \mathrm{OH}$ & 12c & $(\mathrm{A})+(\mathrm{C})$ & 12 \\
\hline 18 & $-\mathrm{OH}$ & $-\mathrm{CH}_{2} \mathrm{OH}$ & 12c & $(\mathrm{A})+(\mathrm{D})^{\mathrm{a}}$ & 77 \\
\hline 19 & $-\mathrm{OH}$ & $-\mathrm{CH}_{2} \mathrm{OH}$ & 12c & $(\mathrm{A})+(\mathrm{D})^{\mathrm{b}}$ & 87 \\
\hline 20 & $-\mathrm{OH}$ & $-\mathrm{COOH}$ & 12d & $(\mathrm{A})$ & Impure \\
\hline 21 & $-\mathrm{OH}$ & $-\mathrm{COOH}$ & 12d & $(\mathrm{A})+(\mathrm{D})^{\mathrm{a}}$ & 70 \\
\hline 22 & $-\mathrm{OH}$ & $-\mathrm{COOH}$ & 12d & $(\mathrm{A})+(\mathrm{D})^{\mathrm{b}}$ & 88 \\
\hline 23 & $-\mathrm{OH}$ & $-\mathrm{CH}_{2} \mathrm{COOH}$ & 12e & $(\mathrm{A})+(\mathrm{C})$ & Complex mixture $^{\mathrm{c}}$ \\
\hline 24 & $-\mathrm{OH}$ & $-\mathrm{CH}_{2} \mathrm{COOH}$ & $12 e$ & $(\mathrm{~A})+(\mathrm{D})^{\mathrm{a}}$ & Complex mixture $^{\mathrm{C}}$ \\
\hline 25 & $-\mathrm{OH}$ & $-\mathrm{CH}_{2} \mathrm{COOH}$ & $12 \mathrm{e}$ & $(\mathrm{A})+(\mathrm{D})^{\mathrm{b}}$ & Complex mixture $^{\mathrm{c}}$ \\
\hline 26 & $-\mathrm{OH}$ & -8-hydroxyquinoline & 12f & (A) & Complex mixture \\
\hline 27 & $-\mathrm{OH}$ & -8-hydroxyquinoline & $12 f$ & $(\mathrm{~A})+(\mathrm{D})^{\mathrm{a}}$ & Complex mixture \\
\hline 28 & $-\mathrm{OH}$ & -8-hydroxyquinoline & $12 f$ & $(\mathrm{~A})+(\mathrm{D})^{\mathrm{b}}$ & Complex mixture \\
\hline 29 & -OMe & $-\mathrm{H}$ & $13 a$ & $(\mathrm{~A})+(\mathrm{D})^{\mathrm{b}}$ & No reaction \\
\hline 30 & -OMe & $-\mathrm{OH}$ & 13b & $(\mathrm{A})+(\mathrm{D})^{\mathrm{b}}$ & No reaction \\
\hline 31 & -OMe & $-\mathrm{CH}_{2} \mathrm{OH}$ & $13 c$ & $(\mathrm{~A})+(\mathrm{D})^{\mathrm{b}}$ & No reaction \\
\hline 32 & -OMe & $-\mathrm{COOH}$ & 13d & $(\mathrm{A})+(\mathrm{D})^{\mathrm{b}}$ & No reaction \\
\hline 33 & -OMe & $-\mathrm{CH}_{2} \mathrm{COOH}$ & 13e & $(A)+(D)^{b}$ & No reaction \\
\hline 34 & -OMe & -8-hydroxyquinoline & 13f & $(\mathrm{A})+(\mathrm{D})^{\mathrm{b}}$ & No reaction \\
\hline
\end{tabular}

${ }^{a}$ Using 1 equiv of NaOAc; ${ }^{b}$ Using 2 equiv of $\mathrm{NaOAc} ;{ }^{\mathrm{c}}$ Mass spectrometry showed that $[\mathrm{M}+\mathrm{H}]^{+}$or $[\mathrm{M}-\mathrm{H}]^{-}$was base peak.

Table 4. Azo coupling reactions performed according to Scheme 3.

\section{Conclusions}

An investigation of solution and solid-state azobenzene coupling processes using a combination of spectroscopic techniques has provided clear evidence of similar pathways for each, resulting from azo-group formation. The solid phase azo-coupling process can be slow and is $\mathrm{pH}$ dependent, and generates modified polymers in the protonated form unless the coupled product is subjected to a base wash. Evidence for para-coupling in solution was obtained, and with increased steric restraints on a surface, it is reasonable to expect that surface couplings are also para directed. Importantly, neither solution nor surface coupling is quantitative, and appropriate reaction time needs to be allowed to ensure high levels of conversion. From the similarities of the UV absorption data between solution and solid phase, there is clear evidence for azo-coupling at the electron-rich activated surface generated after carbene insertion as indicated in Scheme 1, but of interest is that 
recent work has shown that diazonium coupling reactions with Carbon Black may proceed by loss of nitrogen followed by surface coupling in a radical mechanism; $[51,52]$ there is of course the possibility that some similar radical mediated coupling may occur in the system studied here-in. Such azo- couplings may be considered to be another example of "Click"-type chemical modification methodology, suitable for wide application and especially suitable for solid materials.[53]

\section{Acknowledgements}

The authors would like to acknowledge the EPSRC and Oxford Advanced Surfaces for funding to EMP and Dr Robert Jacobs at the University of Oxford for his assistance with the UV spectroscopic analysis. We gratefully acknowledge A*STAR Graduate Academy (A*GA) for funding to SC. We acknowledge a referee for helpful suggestions.

\section{Experimental}

Reactions were carried out in oven-dried flasks open to the atmosphere using standard solvents, petrol refers to petroleum ether with boiling point $40-60{ }^{\circ} \mathrm{C}$. Water refers to the use of de-ionised water. Where necessary, temperatures below room temperature were achieved using cooling baths; ice/ $\mathrm{NaCl} /$ water $\left(-5{ }^{\circ} \mathrm{C}\right)$, ice/water $\left(0{ }^{\circ} \mathrm{C}\right)$ or by standing in the fridge in the case of polymer modification. When possible, reactions were followed with thin layer chromatography (TLC) with Merck aluminium foil backed sheets pre-coated with $0.2 \mathrm{~mm}$ Kieselgel $60 \mathrm{~F}_{254}$ silica gel, product spots were visualised with UV fluorescence $\left(\lambda_{\max } 254 \mathrm{~nm}\right)$. Column chromatography was performed with Merck Geduran Si 60 silica gel (0.040-0.063 mm). Solvents were evaporated under reduced pressure at $40{ }^{\circ} \mathrm{C}$ on a Buchi Rotavapor R-210 with a Vacuubrand CVC2 pump and pressure control system. Characterisation of compounds was done using the following equipment and settings. Melting points were measured with a Stuart Scientific SMP1 melting point apparatus. UV-visible spectra were obtained with a Perkin-Elmer UV Lamda 14P spectrometer with solutions 
in DCM; the path length is $1 \mathrm{~cm}$ and the data is reported in nanometers (nm) with the molar extinction coefficients $\left(\mathrm{dm}^{3} \mathrm{~mol}^{-1} \mathrm{~cm}^{-1}\right)$. Infrared (IR) spectra were recorded on a Bruker Tensor 27 FT-IR spectrometers; selected absorption maxima are reported in wavenumbers $\left(\mathrm{cm}^{-1}\right) .{ }^{1} \mathrm{H}$ NMR were recorded on Bruker DPX200 (200 MHz), DPX400 (400 MHz), DQX400 (400 MHz) and AVC500 (500 MHz) spectrometers and COSY were obtained on a Bruker DQX400 and AVC500.

${ }^{13} \mathrm{C}$ NMR were recorded on DQX400 (100 MHz) and AVC500 (125 MHz) spectrometers, HMBC, HSQC HMQC and DEPT spectra were obtained with these instruments also. Chemical shifts $\left(\delta_{\mathrm{H}}\right.$, $\left.\delta_{C}\right)$ are reported in parts per million $(\mathrm{ppm})$, coupling constants $(J)$ are in hertz $(\mathrm{Hz})$ and the following abbreviations are used: s (singlet), br s (broad singlet), d (doublet), dd (doublet doublet), $\mathrm{t}$ (triplet), q (quartet), m (multiplet), app. (apparent). Low resolution mass spectra $(\mathrm{m} / \mathrm{z})$ were obtained with a Fisons Platform spectrometer with electrospray ionisation (ESI) and a Fisons AutoSpec-oaTpf spectrometer with field ionisation (FI). A Bruker microTOF was used to obtain high resolution mass spectra; $m / z$ values are reported in Daltons and their intensities are a function of the base peak. Diffuse reflectance spectroscopy was performed using an Aglient Cary 4000 UV Vis spectrometer with a Pike Veemac Diffuse IR accessory. Combustion analysis was provided by MEDAC Ltd, Surrey, UK.

\section{Polystyrene materials 4a-4i}

For extensive information concerning preparation and characterisation see our previously published work.[31, 32]

\section{Solution Diazonium couplings}

\section{Procedure A: Procedure for diazonium coupling to $N, N$-dimethylaniline.}

A solution of the amine (1 eq) in $\mathrm{EtOH}$ was stirred at $-5{ }^{\circ} \mathrm{C}$. Isopentyl nitrite (1 eq) and tetrafluoroboric acid (2 eq) were added and the mixture was stirred for 1 hour at $-5{ }^{\circ} \mathrm{C}$. $\quad N, N$ dimethylaniline (1 eq) was added and the mixture stirred at room temperature for the time period 
given in Table 2. The EtOH was removed in vacuo then the residue dissolved in DCM and washed with sat. aq. $\mathrm{K}_{2} \mathrm{CO}_{3}$. The aqueous phase was washed with DCM until the resulting organic phase was colourless. The organic fractions were combined, dried over $\mathrm{MgSO}_{4}$, filtered and concentrated in vacuo. Purification by silica column chromatography was performed if necessary and the yields of the reactions are in Table 2.

\section{Procedure B: Diazonium coupling to $N, N$-dimethyl aniline with adjusted $\mathrm{pH}$.}

A solution of the amine (1 eq) in EtOH was set to stir at $-5{ }^{\circ} \mathrm{C}$. Isopentyl nitrite (1 eq) and tetrafluoroboric acid (2 eq) were added and the mixture was stirred for 1 hour at $-5{ }^{\circ} \mathrm{C}$. Sodium acetate ( 1 eq) followed by $N, N$-dimethylaniline ( 1 eq) were added then the mixture stirred at room temperature for the time periods in Table 2. The EtOH was removed in vacuo then the residue dissolved in DCM and washed with water. The aqueous phase was washed with DCM until the resulting organic phase was colourless. All the organic fractions were combined, dried over $\mathrm{MgSO}_{4}$, filtered and concentrated in vacuo. Purification by silica column chromatography was performed if necessary and the yields are displayed in Table 2.

(E)-4-((4' -(tert-Butyl)phenyl)diazenyl)-N,N-dimethylaniline 6 a.

Product 6a was purified by column chromatography (eluent 20:1 petrol:EtOAc) and isolated as a red solid. $\mathrm{R}_{\mathrm{f}}$ 0.44, 15:1 (petrol:EtOAc); mp 156-158 ${ }^{\circ} \mathrm{C}$ (lit.[54] $\left.137-137.5^{\circ} \mathrm{C}\right) ; \lambda_{\max }\left(\mathrm{CH}_{2} \mathrm{Cl}_{2}\right) / \mathrm{nm}$ $412\left(5040 \mathrm{~mol}^{-1} \mathrm{dm}^{3} \mathrm{~cm}^{-1}\right) ; v_{\max }($ neat $) / \mathrm{cm}^{-1} 2964(\mathrm{C}-\mathrm{H}), 1600(\mathrm{~N}=\mathrm{N}), 1515,1442,1520,1362(\mathrm{C}-\mathrm{N})$, 1229, 1159, 1140, 945, 839, 818; $\delta_{\mathrm{H}}\left(400 \mathrm{MHz}, \mathrm{CDCl}_{3}\right) 1.38\left(9 \mathrm{H}, \mathrm{s}, \mathrm{C}\left(\mathrm{C}_{3}\right)_{3}\right), 3.09(6 \mathrm{H}, \mathrm{s}$, $\left.\mathrm{N}\left(\underline{\mathrm{C}}_{3}\right)_{2}\right), 6.77$ (2H, app. d $J$ 9.2, H-2, 6), 7.51 (2H, app. d $J$ 8.8, H-2 ' , 6 ' ), 7.79 (2H, app. d $J$ 8.8, H-3 ' $5^{\prime}$ ), $7.88\left(2 \mathrm{H}\right.$, app. d $J$ 9.2, H-5, 3); $\delta_{\mathrm{C}}\left(100 \mathrm{MHz}, \mathrm{CDCl}_{3}\right) 31.4\left(\mathrm{C}\left(\underline{\mathrm{C}} \mathrm{H}_{3}\right)_{3}\right), 34.8\left(\underline{\mathrm{C}}\left(\mathrm{CH}_{3}\right)_{3}\right)$, $40.3\left(\mathrm{~N}\left(\underline{\mathrm{CH}}_{3}\right)_{2}\right), 111.5$ (C-2, 6), 121.9 (C-3 ' , 5 ' ), 124.7 (C-3, 5), 125.8 (C-2 ' , 6 ' ), 143.8 (C-1), 151.1 (C-1 '), 152.2 (C-4), 152.7 (C-4 ' ); m/z (ESI $) 282\left([\mathrm{M}+\mathrm{H}]^{+}, 100 \%\right)$; HRMS (ESI $\left.{ }^{+}\right)$calculated for $\mathrm{C}_{18} \mathrm{H}_{24} \mathrm{~N}_{3} \mathrm{~m} / \mathrm{z}[\mathrm{M}+\mathrm{H}]^{+}$: 282.1965; found, 282.1969. 


\section{(E)-4-((4'-Hexylphenyl)diazenyl)- $N, N$-dimethylaniline $6 \mathrm{~b}$.}

Product 6b was purified by silica column chromatography (eluent 20:1 petrol:EtOAc) and was isolated as an orange solid. $\mathrm{R}_{\mathrm{f}} 0.58\left(10: 1\right.$ petrol:EtOAc); m.p. $74{ }^{\circ} \mathrm{C} ; \lambda_{\max }\left(\mathrm{CH}_{2} \mathrm{Cl}_{2}\right) / \mathrm{nm} 410(24000$ $\left.\mathrm{mol}^{-1} \mathrm{dm}^{3} \mathrm{~cm}^{-1}\right) ; v_{\max }($ neat $) / \mathrm{cm}^{-1} 2925(\mathrm{C}-\mathrm{H}), 2854(\mathrm{C}-\mathrm{H}), 1599(\mathrm{~N}=\mathrm{N}), 1515,1443,1400,1393$ (CN), 1230, 1154, 1139, 946, 818; $\delta_{\mathrm{H}}\left(400 \mathrm{MHz}, \mathrm{CDCl}_{3}\right)$ 0.91-0.94 (3H, m, $\left.\underline{\mathrm{H}}_{3} \mathrm{C}_{5} \mathrm{H}_{10} \mathrm{Ar}\right), 1.35$ (6H, br s, $\left.\mathrm{CH}_{3} \underline{\mathrm{C}}_{2} \mathrm{C}_{2} \mathrm{C}_{2} \mathrm{C}_{2} \mathrm{H}_{5} \mathrm{Ar}\right), \quad 1.64-1.72$ (2H, m, $\left.\mathrm{C}_{4} \mathrm{H}_{9} \underline{\mathrm{C}}_{2} \mathrm{CH}_{2} \mathrm{Ar}\right), 2.96$ (2H, t J 7.7, $\left.\mathrm{C}_{5} \mathrm{H}_{11} \underline{\mathrm{C}}_{2} \mathrm{Ar}\right), 3.08$ (6H, s, N($\left.\left.\underline{\mathrm{CH}}_{3}\right)_{2}\right), 6.78$ (2H, app. d $J$ 9.1, H-2, 6), 7.32 (2H, app. d $J$ 8.3, H-2 ' ,

$6^{\text {' }), ~} 7.80$ (2H, app. d $J$ 8.3, H-3 ' , 5 ' ), 7.90 (2H, app. d $J$ 9.1, H-3, 5); $\delta_{\mathrm{C}}\left(100 \mathrm{MHz}, \mathrm{CDCl}_{3}\right) 14.2$

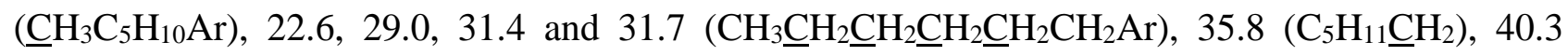
$\left(\mathrm{N}\left(\mathrm{CH}_{3}\right)_{2}\right), 111.5(\mathrm{C}-2,6), 122.2(\mathrm{C}-3,5), 124.8$ (C-3 ' , $5^{\prime}$ ), 129.0 (C-2 ' , 6 ' ), 143.8 (C-1), 144.7 (C-4 ' ), 151.5 (C-1 ' ), 152.2 (C-4); HRMS (ESI ${ }^{+}$) calculated for $\mathrm{C}_{20} \mathrm{H}_{28} \mathrm{~N}_{3} \mathrm{~m} / \mathrm{z}[\mathrm{M}+\mathrm{H}]^{+}:$309.2205; found, 309.2216.

\section{(E)-4-((4'-Iodophenyl)diazenyl)- $N, N$-dimethylaniline $6 c$.}

Product 6c was purified with silica column chromatography (eluent 30:1 petrol:EtOAc) affording an orange solid. $\mathrm{R}_{\mathrm{f}} 0.67$ (4:1 petrol:EtOAc); mp $166-169{ }^{\circ} \mathrm{C}$, lit.[55] $163.5-164{ }^{\circ} \mathrm{C} ; \lambda_{\max }\left(\mathrm{CH}_{2} \mathrm{Cl}_{2}\right) / \mathrm{nm}$

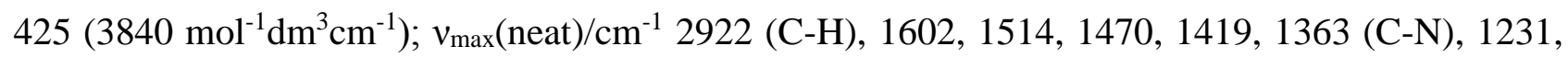
1156, 1051, 827, 733, 700, 649; $\delta_{\mathrm{H}}\left(400 \mathrm{MHz}^{\mathrm{CDCl}} 3\right) 3.10\left(6 \mathrm{H}, \mathrm{s}, \mathrm{N}\left(\mathrm{C}_{3}\right)_{2}\right), 6.76$ (2H, app. d $J$ 9.2, H-2, 6), 7.59 (2H, app. d $J$ 8.6, H-2 ', 6 ' ), 7.81 (2H, app. d $J$ 8.6, H-3 ' , 5 ' ), 7.88 (2H, app. d $J$ 9.2, H-3, 5); $\delta_{\mathrm{C}}\left(100 \mathrm{MHz}, \mathrm{CDCl}_{3}\right) 40.3\left(\mathrm{~N}\left(\underline{\mathrm{CH}}_{3}\right)_{2}\right), 95.2$ (C-4 ' ), 111.5 (C-2, 6), 123.9 (C-2 ' , 6 ' ), 125.2 (C-3, 5), 138.1 (C-3 ' , $5^{\prime}$ ), 143.5 (C-1), 152.6 and 152.6 (C-4, $1^{\prime}$ ); m/z (ESI $) 352\left([\mathrm{M}+\mathrm{H}]^{+}\right.$, 100\%); HRMS (ESI ${ }^{+}$) calculated for $\mathrm{C}_{14} \mathrm{H}_{15} \mathrm{~N}_{3} \mathrm{I} \mathrm{m/z}[\mathrm{M}+\mathrm{H}]^{+}$: 352.0305; found, 352.0315.

\section{(E)-4-((4'-Diethyl benzylphosphonate))diazenyl)- $N, N$-dimethylaniline $6 \mathrm{e}$.}

Product 6e was purified by silica column chromatography (eluent 1:1 petrol:EtOAc) to give an orange solid. $\mathrm{R}_{\mathrm{f}} 0.61$ (1:1 petrol:EtOAc); m.p. $101-105{ }^{\circ} \mathrm{C} ; \lambda_{\max }\left(\mathrm{CH}_{2} \mathrm{Cl}_{2}\right) / \mathrm{nm} 416\left(2500 \mathrm{~mol}^{-}\right.$ 
$\left.{ }^{1} \mathrm{dm}^{3} \mathrm{~cm}^{-1}\right) ; v_{\max }($ neat $) / \mathrm{cm}^{-1} 2903(\mathrm{C}-\mathrm{H}), 1599(\mathrm{~N}=\mathrm{N}), 1518,1442,1401,1363(\mathrm{C}-\mathrm{N}), 1350,1156$, $1136(\mathrm{P}=\mathrm{O}), 1025$ (P-OEt), 956; $\delta_{\mathrm{H}}\left(400 \mathrm{MHz}, \mathrm{CDCl}_{3}\right) 1.25\left(6 \mathrm{H}, \mathrm{t} J\right.$ 7.1, $\left.\mathrm{P}(\mathrm{O})\left(\mathrm{OCH}_{2} \mathrm{C}_{3}\right)_{2}\right), 3.07$

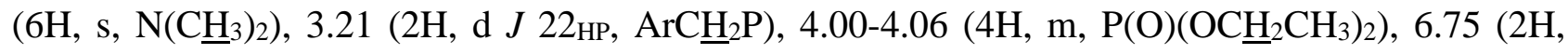
app. d $J$ 9.1, H-2, 6), 7.40 (2H, app. dd $J_{\mathrm{HH}} 7.6$ and $J_{\mathrm{HP}} 2.2, \mathrm{H}-3^{\prime}$, 5 ' ), 7.80 (2H, d $J$ 7.6, H-2 ' , 6 ' ), 7.87 (2H, d J 9.1, H-3, 5); $\delta_{\mathrm{C}}\left(100 \mathrm{MHz}, \mathrm{CDCl}_{3}\right) 16.3\left(\mathrm{P}(\mathrm{O})\left(\mathrm{OCH}_{2} \underline{\mathrm{C}} \mathrm{H}_{3}\right)_{2}, 33.1\left(\mathrm{~d} J\right.\right.$ 138.2, $\left.\mathrm{ArCH}_{2} \mathrm{P}\right)$, $40.3\left(\mathrm{~N}\left(\underline{\mathrm{CH}}_{3}\right)_{2}\right), 62.3\left(\mathrm{P}(\mathrm{O})\left(\mathrm{O}_{\mathrm{CH}} \mathrm{CH}_{3}\right)_{2}\right), 111.5$ (C-2, 6), 122.3 (C-2 ' , 6 ' ), 124.9 (C-3, 5), 130.3 (C-3 ' , $5^{\prime}$ ), $132.9\left(\mathrm{C}-1^{\prime}\right.$ ), 143.6 (C-1), 152.1 and $152.4(\mathrm{C}-4$ and C-4 ' ); m/z (ESI $) 751\left([2 \mathrm{M}+\mathrm{H}]^{+}\right.$, 100\%), $376\left([\mathrm{M}+\mathrm{H}]^{+}, 40 \%\right)$; HRMS $\left(\mathrm{ESI}^{+}\right)$calculated for $\mathrm{C}_{19} \mathrm{H}_{27} \mathrm{~N}_{3} \mathrm{O}_{3} \mathrm{P} \mathrm{m} / \mathrm{z}[\mathrm{M}+\mathrm{H}]^{+}: 376.1785$; found, 376.1786.

\section{(E)-4-((4'-Aminophenyl))diazenyl)- $N, N$-dimethylaniline $6 f$.}

Product 6f was purified by silica column chromatography (eluent 10:1 petrol:EtOAc to EtOAc) and was isolated as an dark brown oily solid that was contaminated with an unknown impurity. $\lambda_{\max }$ $\left(\mathrm{CH}_{2} \mathrm{Cl}_{2}\right) / \mathrm{nm} 413\left(5980 \mathrm{~mol}^{-1} \mathrm{dm}^{3} \mathrm{~cm}^{-1}\right) ; v_{\max }$ (neat)/cm 3336 (N-H), 2917 (C-H), 1599, 1517, 1362 (C-N), 1149, 823; $\delta_{\mathrm{H}}\left(400 \mathrm{MHz}, \mathrm{CDCl}_{3}\right) 3.08$ (6H, s, N(C $\left.\left.\underline{\mathrm{H}}_{3}\right)_{2}\right), 6.76$ (2H, app. d J 9.1, H-2, 6), 6.92 (2H, app. d $J$ 8.8, H-3 ' , $5^{\prime}$ ), 7.79 (2H, app. d $J$ 8.8, H-2 ' , 6 ' ), 7.84 (2H, app. d $J$ 9.1, H-3,5); $\delta_{\mathrm{C}}$

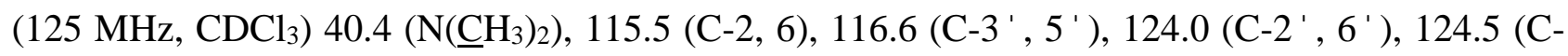
$3^{\prime}, 5^{\prime}$ ), 143.6 (C-1), 147.5 (C-4 ' ), 152.0 (C-1 ' ), 157.2 (C-4); m/z (ESI $) 241\left([\mathrm{M}+\mathrm{H}]^{+}, 25 \%\right)$.

\section{(E)-4-((4'-Phenylacetic acid))diazenyl)- $N, N$-dimethylaniline $6 g$.}

Product 6g was purified by silica column chromatography (eluent 6:1 petrol:EtOAc to 1:5 MeOH:EtOAc) and isolated as a black solid. $\mathrm{R}_{\mathrm{f}} 0.38$ (1:6 petrol:EtOAc); m.p. 166-168 ${ }^{\circ} \mathrm{C}$; $\lambda_{\max }\left(\mathrm{CH}_{2} \mathrm{Cl}_{3}\right) / \mathrm{nm} 415\left(10000 \mathrm{~mol}^{-1} \mathrm{dm}^{3} \mathrm{~cm}^{-1}\right) ; v_{\max } / \mathrm{cm}^{-1}$ 2918, $1709(\mathrm{C}=\mathrm{O}), 1599(\mathrm{~N}=\mathrm{N}), 1517,1357$ (C-N), 1250, 1138, 820; $\delta_{\mathrm{H}}\left(400 \mathrm{MHz}, \mathrm{CDCl}_{3}\right) 3.10\left(6 \mathrm{H}, \mathrm{s}, \mathrm{N}\left(\underline{\mathrm{C}}_{3}\right)_{2}\right), 3.72\left(2 \mathrm{H}, \mathrm{s}, \mathrm{ArC}_{2} \mathrm{COOH}\right)$, 6.85 (2H, app. d $J$ 9.1, H-2, 6), 7.47 (2H, app. d $J$ 8.5, H-2 ' , 6 ' ), 7.80 (2H, app. d $J$ 8.5, H-3 ' , 5 ' ), 7.85 (2H, app. d J 9.1, H-3, 5); $\delta_{\mathrm{C}}\left(100 \mathrm{MHz}, \mathrm{CDCl}_{3}\right) 39.8\left(\mathrm{~N}\left(\underline{\mathrm{CH}}_{3}\right)_{2}\right), 40.6\left(\mathrm{ArCH}_{2} \mathrm{COOH}\right), 111.9$ 
(C-2, 6), 122.3 (C-3 ' , 5 ' ), 125.1 (C-3, 5), 130.4 (C-2 ' , 6 ' ), 137.0 (C-4 ' ), 143.8 (C-1), 132.4 (C-

$\left.1^{\prime}\right), 153.2(\mathrm{C}-4), 205.8(\underline{\mathrm{C}}=\mathrm{O}) ; \mathrm{m} / \mathrm{z}\left(\mathrm{ESI}^{+}\right) 306\left([\mathrm{M}+\mathrm{Na}]^{+}, 30 \%\right)$; HRM $\left(\mathrm{ESI}^{+}\right)$calculated for $\mathrm{C}_{16} \mathrm{H}_{18} \mathrm{~N}_{3} \mathrm{O}_{2} \mathrm{~m} / \mathrm{z}[\mathrm{M}+\mathrm{Na}]^{+}$: 306.1213; found, 306.1206.

\section{1,3-Bis(4-iodophenyl)triaz-1-ene 7.}

Product 7 was generated as a pale yellow solid as a by-product in the reaction of $N$, $N$-dimethyl aniline with the iodo diazonium salt. $\mathrm{R}_{\mathrm{f}} 0.68$ (10:1 petrol:EtOAc); mp 170-173 ${ }^{\circ} \mathrm{C}$; $\mathrm{v}_{\max }(\mathrm{neat}) / \mathrm{cm}^{-1}$ 3200, $2923(\mathrm{C}-\mathrm{H}), 2853(\mathrm{C}-\mathrm{H})$, 1586, 1501, 1476; $\delta_{\mathrm{H}}\left(100 \mathrm{MHz}, \mathrm{CDCl}_{3}\right) 7.14(4 \mathrm{H}, \mathrm{AA}$ ' BB ' d, ArH-2, 6, $2^{\prime}$, 6 ' ), 7.69 (4H, AA 'BB ' d, ArH-3, 5, 3 ' , 5 ' ); $\delta_{\mathrm{C}}\left(100 \mathrm{MHz}, \mathrm{CDCl}_{3}\right) 119.8$ (ArC-2, 6, $2^{\prime}, 6^{\prime}$ ), 138.3 (ArC-3, 5, 3 ', $5^{\prime}$ ), other carbons not detectable due to contamination; $\mathrm{m} / \mathrm{z}\left(\mathrm{ESI}^{-}\right)$ 447.9 ([M-H]-, 100\%); HRMS (ESI') 447.8808 found, 447.8808 expected.

\section{Procedure C: Diazonium salt formation and Solution coupling.}

The corresponding amine (1.00 eq) was dissolved solvent (EtOH or THF: $\left.\mathrm{H}_{2} \mathrm{O}=1: 1\right)$. 3M $\mathrm{HCl}(2.00$ eq) was added into the mixture and stirred in ice-bath for $10 \mathrm{~min}$. $\mathrm{NaNO}_{2}$ (1.20 eq) dissolved in approximately $1 \mathrm{~mL} \mathrm{H}_{2} \mathrm{O}$ was then added into the cold mixture. The mixture was stirred in ice-bath for 30 - 40 min before $\mathrm{H}$-acid was performed to test for presence of diazonium salt. The diazonium salt reaction mixture was used immediately in situ.

Alternative method: The corresponding amine (1.00 eq) was added into a stirring solution of EtOH $(15 \mathrm{~mL})$ at $0{ }^{\circ} \mathrm{C}$ in the dark. Isopentyl nitrite (1.20 eq) was added, followed by tetrafluoroboric acid (2.00 eq) into the reaction mixture, which was then continued to be stirred at $0^{\circ} \mathrm{C}$ in the dark for 50 mins. H- acid test was conducted to detect presence of diazonium functional group. The mixture was used directly.

NaOAc (246 mg, $3.00 \mathrm{mmol}, 2.00$ eq) was added into the diazonium salt mixture in ice bath and stirred for $5 \mathrm{~min}$, before phenol (141 mg, $1.50 \mathrm{mmol}, 1.00 \mathrm{eq})$ dissolved in $1 \mathrm{~mL}$ of THF [or dimethylaniline (1.50 mmol, $1.00 \mathrm{eq})$ ] was added. The reaction mixture was then stirred for $18 \mathrm{~h}$ 
before THF was removed in vacuo .The precipitated product was collected on a Büchner funnel, washed with $\mathrm{H}_{2} \mathrm{O}$ and dried. Alternatively, if there were no precipitated product formed, the reaction mixture was extracted with DCM. The combined organic layers were dried over $\mathrm{MgSO}_{4}$, concentrated and purified using flash column chromatography

\section{Synthesis of N,N-dimethyl-4-(phenyldiazenyl)aniline 11a.}

Using Procedure C, aniline 9a $(0.14 \mathrm{~mL}, 1.50 \mathrm{mmol}, 1.00 \mathrm{eq})$ was reacted with $N, N$-dimethylaniline 8a $(0.14 \mathrm{~mL}, 1.50 \mathrm{mmol}, 1.00 \mathrm{eq})$ in $1 \mathrm{~mL}$ THF to give the product 11a (331mg, 98\%) as an orange-yellow solid; m.p.: $105-107{ }^{\circ} \mathrm{C}$ (lit. $111^{\circ} \mathrm{C}$ ); $v_{\max } / \mathrm{cm}^{-1}$ 2914, 1600 (C=C), 1564, 1516, 1407, 1364, 1139, $821 \mathrm{~cm}^{-1} ; \delta_{\mathrm{H}}\left(400 \mathrm{MHz}, \mathrm{CDCl}_{3}\right) 7.91(2 \mathrm{H}, \mathrm{d}, J=8.5 \mathrm{~Hz}, \mathrm{H}-3), 7.86(2 \mathrm{H}, \mathrm{d}, J=$ $7.6 \mathrm{~Hz}, \mathrm{H}-6), 7.48$ (2H, t, $J=7.3 \mathrm{~Hz}, \mathrm{H}-7), 7.39$ (1H, tt, $J=7.3,1.7 \mathrm{~Hz}, \mathrm{H}-8), 6.79$ (2H, d, $J=9.1$

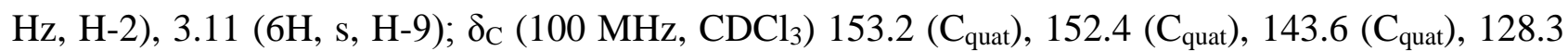
(C-8), 128.9 (C-7), 124.9 (C-3), 122.1 (C-6), 111.4 (C-2), 40.2 (C-9). HRMS (ESI') calculated for $\mathrm{C}_{14} \mathrm{H}_{15} \mathrm{~N}_{3} \mathrm{~m} / \mathrm{z}[\mathrm{M}+\mathrm{H}]^{+}$: 226.1339; found: 226.1342.

\section{Synthesis of (4-((4'-(dimethylamino)phenyl)diazenyl)phenyl)methanol 11c.}

Using Procedure C, 4-aminobenzyl alcohol 9c (185 mg, $1.50 \mathrm{mmol}, 1.00$ eq) was reacted with $N, N$ dimethylaniline 8a $(0.14 \mathrm{~mL}, 1.50 \mathrm{mmol}, 1.00 \mathrm{eq})$ in $1 \mathrm{~mL}$ THF to give the product 11c (368 mg, 96\%.) as a bright orange solid; m.p.: $195-197{ }^{\circ} \mathrm{C} ; v_{\max } / \mathrm{cm}^{-1} 3352,1976,1609(\mathrm{C}=\mathrm{C}), 1555(\mathrm{~N}=\mathrm{N})$, 1522, 1442, 1374, 1231, 11588, 1051 (C-O) $\mathrm{cm}^{-1} ; \delta_{\mathrm{H}}\left(400 \mathrm{MHz}, \mathrm{CD}_{3} \mathrm{SOCD}_{3}\right) 7.78$ (2H, d, $J=9.0$ Hz, H-2'), 7.75 (2H, d, $J=8.3 \mathrm{~Hz}, \mathrm{H}-2), 7.46$ (2H, d, $J=8.3 \mathrm{~Hz}, \mathrm{H}-3), 6.83$ (2H, d, $J=9.1 \mathrm{~Hz}, \mathrm{H}-$ 3'), $5.31(1 \mathrm{H}, \mathrm{t}, J=5.6 \mathrm{~Hz},-\mathrm{OH}), 4.57$ (2H, d, $J=5.6 \mathrm{~Hz}, \mathrm{H}-5), 3.05$ (6H, s, H-5') ; $\delta_{\mathrm{C}}(100 \mathrm{MHz}$,

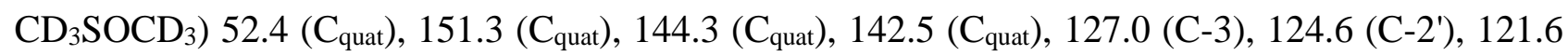
(C-2), 111.5 (C-3'), 62.5 (C-5), 39.8 (C-5'). HRMS (ESI ${ }^{+}$) calculated for $\mathrm{C}_{15} \mathrm{H}_{17} \mathrm{~N}_{3} \mathrm{O} \mathrm{m} / \mathrm{z}[\mathrm{M}+\mathrm{H}]^{+}$: 256.14444; found: 256.14410. 
Using Procedure C, 4-aminobenzoic acid 9d (206 mg, $1.50 \mathrm{mmol}, 1.00 \mathrm{eq)}$ was reacted with $N, N$ dimethylaniline 8a $(0.14 \mathrm{~mL}, 1.50 \mathrm{mmol}, 1.00 \mathrm{eq})$ in $1 \mathrm{~mL}$ THF to give the product $\mathbf{1 1 d}$ (394 $\mathrm{mg}$, 97\%.) as a bright red solid; m.p.: $>250{ }^{\circ} \mathrm{C}$ (lit. $\left.179-182^{\circ} \mathrm{C}\right) ; v_{\max } / \mathrm{cm}^{-1} 2822,1994,1676(\mathrm{C}=\mathrm{O})$, $1594(\mathrm{C}=\mathrm{C}), 1556(\mathrm{~N}=\mathrm{N}), 1421,1361,(\mathrm{C}-\mathrm{N}), 1252,1136 \mathrm{~cm}^{-1} ; \delta_{\mathrm{H}}\left(400 \mathrm{MHz}, \mathrm{CD}_{3} \mathrm{SOCD}_{3}\right) 13.07$ (1H, broad s, -OH), 8.07 (2H, d, J = 8.5 Hz, H-3), 7.83 (2H, d, J = $8.5 \mathrm{~Hz}, \mathrm{H}-2), 7.82$ (2H, d, J = 9.3 Hz, H-2'), 6.84 (2H, d, J = 9.3 Hz, H-3'), 3.07 (6H, s, H-5'); $\delta_{\mathrm{C}}\left(100 \mathrm{MHz}, \mathrm{CD}_{3} \mathrm{SOCD}_{3}\right) 166.9$ (-

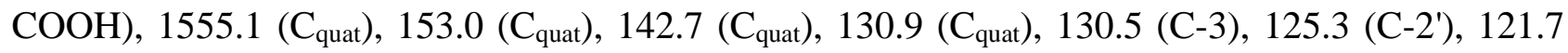
(C-2), 111.6 (C-3'), 39.8 (C-5'). HRMS (ESI ${ }^{+}$) calculated for $\mathrm{C}_{15} \mathrm{H}_{15} \mathrm{~N}_{3} \mathrm{O}_{2} \mathrm{~m} / \mathrm{z}[\mathrm{M}+\mathrm{H}]^{+}$: 270.12370 ; found: 270.12344 .

\section{Synthesis of 4-(phenyldiazenyl)phenol 12a.}

Using Procedure C, aniline 9a (0.14 mL, $1.50 \mathrm{mmol}, 1.00$ eq) was reacted with phenol $8 \mathbf{b}$ (141 mg, $1.50 \mathrm{mmol}, 1.00 \mathrm{eq})$ in $1 \mathrm{~mL}$ THF to give the product 12a as an orange-yellow solid m.p. 155 -157 ${ }^{\circ} \mathrm{C}$ (lit. $152-155^{\circ} \mathrm{C}$ ) after purification by flash column chromatography, eluting product at Petrol 40-60: $\mathrm{EA}=30: 1 . \mathrm{Rf}=0.54$ in Petrol 40-60:EA = 4:1; $(244 \mathrm{mg}, 82 \%$ - when 1.00 eq of NaOAc used; and 280 mg, 95\% - when 2.00 eq of NaOAc used; $v_{\max } / \mathrm{cm}^{-1} 2161,1977,1582,1503,1413$, 1268, 1219, 1142, $993 \mathrm{~cm}^{-1} ; \delta_{\mathrm{H}}(400 \mathrm{MHz}, \mathrm{MeOD}) 7.81$ - 7.84 (4H, m, H-3, 6), $7.44-7.48$ (2H, m, H-7) 7.38 - 7.42 (1H, m, H-8), 6,92 (2H, app d, $J=8.8 \mathrm{~Hz}, \mathrm{H}-2)$; $\delta_{\mathrm{C}}(100 \mathrm{MHz}, \mathrm{MeOD}) 162.0$ (C quat $), 154.0\left(\mathrm{C}_{\text {quat }}\right), 147.4\left(\mathrm{C}_{\text {quat }}\right), 131.2$ (C-8), 130.0 (C-7), 125.9 (C-3/6), 123.3 (C-3/6), 116.7 (C2). HRMS (ESI ${ }^{+}$) calculated for $\mathrm{C}_{12} \mathrm{H}_{10} \mathrm{~N}_{2} \mathrm{O}_{2} \mathrm{~m} / \mathrm{z}[\mathrm{M}+\mathrm{H}]^{+}$: 199.08659; found: 199.08676.

\section{Synthesis of 4-((4'-(hydroxymethyl)phenyl)diazenyl)phenol 12c.}

Using Procedure C, 4-aminobenzyl alcohol 9c (185 mg, $1.50 \mathrm{mmol}, 1.00 \mathrm{eq})$ was reacted with phenol $8 \mathbf{b}$ (141 mg, $1.50 \mathrm{mmol}, 1.00 \mathrm{eq}$ ) in $1 \mathrm{~mL}$ THF to give the product 12c as a brown solid m.p. 198 - $200{ }^{\circ} \mathrm{C}$; (264mg, 77\% - when 1.00 eq of NaOAc used; and 297 mg, 87\% - when 2.00 eq of NaOAc used); $v_{\max } / \mathrm{cm}^{-1}$ 3385, 2160, $1594(\mathrm{~N}=\mathrm{N}), 1500,(\mathrm{C}=\mathrm{C}), 1238,1199,1142,1103 \mathrm{~cm}^{-1} ; \delta_{\mathrm{H}}$ 
(400 MHz, MeOD) 7.80 - 7.83 (4H, m, H-2, 2'), 7.50 (2H, d, $J=8.6$ Hz, H-3'), 6.91 (2H, d, $J=9.0$

Hz, H-3), 4.68 (2H, s, H-5'); $\delta_{\mathrm{C}}(100 \mathrm{MHz}, \mathrm{MeOD}) 162.1$ (C quat), 153.4 (Cquat), 147.5 (C quat), 145.3

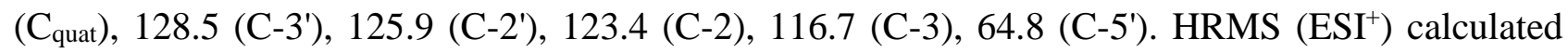
for $\mathrm{C}_{13} \mathrm{H}_{12} \mathrm{~N}_{2} \mathrm{O}_{2} \mathrm{~m} / \mathrm{z}[\mathrm{M}+\mathrm{H}]^{+}$: 229.09715; found: 229.09715 .

\section{Synthesis of 4-((4'-hydroxyphenyl)diazenyl)benzoic acid 12d.}

Using Procedure C, 4-aminobenzoic acid 9d (206 mg, $1.50 \mathrm{mmol}$, 1.00eq) was reacted with phenol 8b (141 mg, $1.50 \mathrm{mmol}, 1.00 \mathrm{eq}$ ) in $1 \mathrm{~mL}$ THF to give the product 12d as an orange-yellow solid, m.p. $>250{ }^{\circ} \mathrm{C}$ (lit. $270-280^{\circ} \mathrm{C}$ ); (318mg, 88\% - when 1.00 eq of NaOAc used; and $332 \mathrm{mg}, 92 \%$ when 2.00 eq of NaOAc used); $v_{\max } / \mathrm{cm}^{-1}$ 3542, 3447, $1663(\mathrm{C}=\mathrm{O}), 1588(\mathrm{~N}=\mathrm{N}), 1500(\mathrm{C}=\mathrm{C}), 1429$, 1283, 1143, $912 \mathrm{~cm}^{-1} ; \delta_{\mathrm{H}}(400 \mathrm{MHz}, \mathrm{MeOD}) \delta 8.16(2 \mathrm{H}, J=8.8 \mathrm{~Hz}, \mathrm{H}-3), 7.89$ (2H, d, $J=8.6 \mathrm{~Hz}$, H-2), 7.86 (2H, d, $\left.J=8.8 \mathrm{~Hz}, \mathrm{H}-2^{\prime}\right), 6.93\left(2 \mathrm{H}, \mathrm{d}, J=8.8 \mathrm{~Hz}, \mathrm{H}-3^{\prime}\right) ; \delta_{\mathrm{C}}(100 \mathrm{MHz}, \mathrm{MeOD}) 169.2$

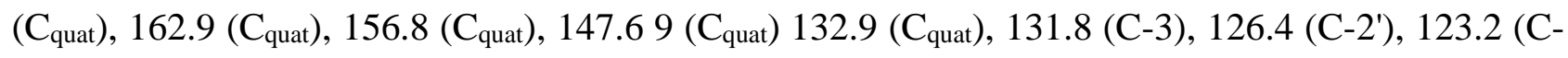
2), $116.8\left(\mathrm{C}-3^{\prime}\right)$. HRMS (ESI ${ }^{+}$) calculated for $\mathrm{C}_{13} \mathrm{H}_{10} \mathrm{~N}_{2} \mathrm{O}_{3} \mathrm{~m} / \mathrm{z}[\mathrm{M}+\mathrm{H}]^{+}$: 241.06077; found: 241.06173.

\section{References}

[1] D. Wang, X. Wang, Amphiphilic azo polymers: Molecular engineering, self-assembly and photoresponsive properties, Prog. Polym. Sci., 38 (2013) 271- 301.

[2] F. Ercole, T.P. Davis, R.A. Evans, Photo-responsive systems and biomaterials: photochromic polymers, light-triggered self-assembly, surface modification, fluorescence modulation and beyond, Polym. Chem., 1 (2010) 37-54.

[3] N. Katsonis, M. Lubomska, M.M. Pollard, B.L. Feringa, P. Rudolf, Synthetic light-activated molecular switches and motors on surfaces, Prog. Surf. Sci., 82 (2007) 407-434.

[4] E. Merino, Synthesis of azobenzenes: the coloured pieces of molecular materials Chem. Soc. Rev., 40 (2011) 3835-3853.

[5] S. Xie, A. Natansohn, P. Rochon, Recent developments in aromatic azo polymers research, Chemistry of Materials, 5 (1993) 403-411.

[6] H. Zollinger, Color Chemistry, 3rd ed., Wiley-VCH, 1991.

[7] S. Mahouche-Chergui, S. Gam-Derouich, C. Mangeney, M.M. Chehimi, Aryl diazonium salts: a new class of coupling agents for bonding polymers, biomacromolecules and nanoparticles to surfaces, Chem. Soc. Rev., 40 (2011) 4143-4166.

[8] J. Zhang, Y. Men, S. Lv, L. Yi, J.-F. Chen, Protein tetrazinylation via diazonium coupling for covalent and catalyst-free bioconjugation, Org. Biomol. Chem., 13 (2015) 11422-11425. 
[9] J. Wang, B. Wu, S. Li, G. Sinawang, X. Wang, Y. He, Synthesis and Characterization of Photoprocessable Lignin-Based Azo Polymer, ACS Sustainable Chemistry \& Engineering, 4 (2016) 4036-4042.

[10] Y. He, Y. Zhu, Z. Chen, W. He, X. Wang, Remote-control photocycloreversion of dithienylethene driven by strong push-pull azo chromophores, Chemical Communications, 49 (2013) 5556-5558.

[11] J. Wang, S. Wang, Y. Zhou, X. Wang, Y. He, Fast Photoinduced Large Deformation of Colloidal Spheres from a Novel 4-arm Azobenzene Compound, ACS Applied Materials \& Interfaces, 7 (2015) 16889-16895.

[12] V. Ferri, M. Elbing, G. Pace, M.D. Dickey, M. Zharnikov, P. Samori, M. Mayor, M.A. Rampi, Light-powered electrical switch based on cargo-lifting azobenzene monolayers, Angew. Chem., Int. Ed. Engl., 47 (2008) 3407-3409.

[13] W. Yongqiang, Y. Wenhui, M. Lingjie, F. Min, J. Guiyuan, Y. Wenfang, Z. Yuqi, G. Hongjun, J. Lei, S. Yanlin, Photochemical-controlled switching based on azobenzene monolayer modified silicon (111) surface, J. Phys. Chem. B, 109 (2005) 14465-14468.

[14] N. Wagner, P. Theato, Light-induced wettability changes on polymer surfaces, Polymer, 55 (2014) 3436-3453.

[15] Z. Yuan, W. Rong, Y. Shouliang, L. Setiawan, H. Xiao, A.G. Fane, Novel chemical surface modification to enhance hydrophobicity of polyamide-imide (PAI) hollow fiber membranes, J. Membr. Sci., 380 (2011).

[16] Y. Zakrevskyy, M. Richter, S. Zakrevska, N. Lomadze, R. von Klitzing, S. Santer, LightControlled Reversible Manipulation of Microgel Particle Size Using Azobenzene-Containing Surfactant, Adv. Funct. Mater., 22 (2012) 5000-5009.

[17] X. Pei, A. Fernandes, B. Mathy, X. Laloyaux, B. Nysten, O. Riant, A.M. Jonas, Correlation between the Structure and Wettability of Photoswitchable Hydrophilic Azobenzene Monolayers on Silicon, Langmuir, 27 (2011) 9403-9412.

[18] H.M.D. Bandara, S.C. Burdette, Photoisomerization in different classes of azobenzene, Chem. Soc. Rev., 41 (2012) 1809-1825.

[19] G.S. Kumar, D.C. Neckers, Photochemistry Of Azobenzene-Containing Polymers, Chem. Rev., 89 (1989) 1915-1925.

[20] Y. Wu, S. Wu, X. Tian, X. Wang, W. Wu, G. Zou, Q. Zhang, Photoinduced reversible gel-sol transitions of dicholesterol-linked azobenzene derivatives through breaking and reforming of van der Waals interactions, Soft Matter, 7 (2011) 716-721.

[21] M. Kamruzzaman, Y. Kuwahara, T. Ogata, S. Ujiie, S. Kurihara, Substituent effects on thermal and photo-alignment behavior of poly(ethylene imine)s carrying azobenzene side groups, Polym. Int., 60 (2011) 730-737.

[22] C. Renner, L. Moroder, Azobenzene as conformational switch in model peptides, ChemBioChem, 7 (2006) 868-878.

[23] O. Pieroni, A. Fissi, N. Angelini, F. Lenci, Photoresponsive polypeptides, Acc. Chem. Res., 34 (2001) 9-17.

[24] M. Tabachnick, H. Sobotka, Spectrophotometric Studies Of Amino Acid Azo Derivatives, J. Biol. Chem., 234 (1959) 1726-1730.

[25] M. Tabachnick, H. Sobotka, Azoproteins II. A Spectrophotometric Study Of The Coupling Of Diazotized Arsanilic Acid With Proteins, J. Biol. Chem., 235 (1960) 1051-1054.

[26] A.V. Luisada-Opper, H. Sobotka, J.D. Chanley, Azoproteins III. Coupling Of Acetylated Bovixe Serum Albumin With Arsanilic Acid And P-Aminobenzoic Acid., J. Biol. Chem., 236 (1961) 2250-2253.

[27] J.E. Sheldon, M.M. Dcona, C.E. Lyons, J.C. Hackett, M.C.T. Hartman, Photoswitchable anticancer activity via trans-cis isomerization of a combretastatin A-4 analog, Org. Biomol. Chem., 14 (2016) 40-49. 
[28] J.-P. Griffiths, D.M.L. Leonard, M.G. Moloney, N.J. Stratton, Control Of Wetting Behavior Using Post-Polymerization Modifications Of Surface Chemical Functionality, J. Mol. Eng. Mater., 1 (2012) 1250002.

[29] J.P. Griffiths, B. Maliha, M.G. Moloney, A.L. Thompson, Surface Functional Polymers by Post-Polymerization Modification using Diarylcarbenes: Introduction, Release and Regeneration of Hydrogen Peroxide and Bactericidal Activity, Langmuir, 26 (2010) 14142-14153.

[30] D. Leonard, M.G. Moloney, C. Thompson, Chemical modification of materials by reaction with diaryl diazomethanes, Tetrahedron Lett., 50 (2009) 3499-3502.

[31] K. Awenat, P.J. Davis, M.G. Moloney, W. Ebenezer, A Chemical Method for the Surface Functionalisation of Polymers, Chem. Commun., (2005) 990 - 992.

[32] C. Choong, J.S. Foord, J.-P. Griffiths, E.M. Parker, B. Luo, M. Bora, M.G. Moloney, Postpolymerisation modification of surface chemical functionality and its effect on protein binding, New J. Chem., 36 (2012) 1187-1200.

[33] H. Wang, J.-P. Griffiths, R.G. Egdell, M.G. Moloney, J.S. Foord, Langmuir, 24 (2008) 862868.

[34] Rau, H. Photochemistry and Photophysics; Rabek, J. F., Ed.; Vol.11, Chapter 4, CRC Press: Boca Raton, FL, 1990.

[35] R.M. Parker, J.C. Gates, H.L. Rogers, P.G.R. Smith, M.C. Grossel, Using the photoinduced reversible refractive-index change of an azobenzene co-polymer to reconfigure an optical Bragg grating, J. Mat. Chem., 20 (2010) 9118-9125.

[36] A. Goulet-Hanssens, K.L.W. Sun, T.E. Kennedy, C.J. Barrettt, Photoreversible Surfaces to Regulate Cell Adhesion, Biomacromolecules, 13 (2012) 2958-2963.

[37] C. Jin, R. Yan, J. Huang, Cellulose substance with reversible photo-responsive wettability by surface modification, J. Mat. Chem., 21 (2011) 17519-17525.

[38] P.F. Gordon, P. Gregory, Organic Chemistry in Colour, Springer-Verlag Berlin Heidelberg New York, Berlin, 1983.

[39] R. Kaminski, U. Lauk, P. Skrabal, H. Zollinger, Mechanism Of Azo Coupling Reactions .33. Ph-Dependence And Micromixing Effects On The Product Distribution Of Couplings With 6Amino-4-Hydroxy-2-Naphthalenesulfonic Acid - Evidence For N-Coupling Of A Naphthylamine Derivative, Helv. Chim. Acta, 66 (1983) 2002-2017.

[40] B.B. Thompson, P.G. Kulkarni, Sulfones Of Potential Medicinal Value .I. Diazonium Coupling Products Of Ethyl P-Toluenesulfonylacetate, J. Pharm. Sci., 58 (1969) 623-\&.

[41] H. Zollinger, The Kinetics Of The Diazo Coupling Reaction, Chem. Rev., 51 (1952) 347-361.

[42] D. Crich, X.L. Hao, Generation and cyclization of acyl radicals from thiol esters under nonreducing, tin-free conditions, J. Org. Chem., 62 (1997) 5982-5988.

[43] J.H. Gardner, L. Joseph, Some Coloured Local Anesthetics, J. Am. Chem. Soc., 57 (1935) 1.

[44] R.M. Christie, Colour Chemistry, Royal Society of Chemistry, Cambridge, 2001.

[45] E. Work, T.S. Work, Chemical Modification of Proteins, (1976) Elsevier Science.

[46] N. Oger, M. d'Halluin, E. Le Grognec, F. Felpin, Using Aryl Diazonium Salts in PalladiumCatalyzed Reactions under Safer Conditions, Org. Process Res. Dev., 18 (2014) 1786-1801.

[47] I. Szele, H. Zollinger, Azo coupling reactions structures and mechanisms, Springer Berlin, 1983.

[48] R.E. Banks, A.R. Thompson, H.S. Vellis, Azo-coupling of 2,3,5,6-tetrafluoropyridine-4diazonium fluoride with mesitylene and anisole. , J. Fluor. Chem., 22 (5) (1983) 499-501.

[49] M.G. Bartle, R.K. Mackie, J.M. Tedder, Reaction of 2,4-dinitrobenzenediazonium ions with thiophens. An acidic Gomberg reaction. , Chem. Commun., 7 (1974) 271-272.

[50] C.L. Bagwell, D.M.L. Leonard, J.-P. Griffiths, M.G. Moloney, N.J. Stratton, D.P. Travers, Post-Polymerization Modification of Materials using Diaryldiazomethanes: Changes to Surface Macroscopic Properties, Macromol. React. Eng., 8 (2014) 170-180.

[51] M. Toupin, D. Belanger, Spontaneous Functionalization of Carbon Black by Reaction with 4Nitrophenyldiazonium Cations, Langmuir, 24 (2008) 1910-1917. 
[52] M. Toupin, D. Belanger, Thermal Stability Study of Aryl Modified Carbon Black by in Situ Generated Diazonium Salt, J. Phys. Chem. C, 111 (2007) 5394-5401.

[53] B.S. Sumerlin, A.P. Vogt, Macromolecular Engineering through Click Chemistry and Other Efficient Transformations, Macromolecules, 43 (2010) 1-13.

[54] P.N. Juri, R.A. Bartsch, Mechanism Of Azo Coupling In Nonpolar Media, J. Org. Chem., 44 (1979) 143-145.

[55] T.W. Campbell, D.A. Young, M.T. Rogers, The Electric Moments of Some Azo Dyes, J. Am. Chem. Soc., 73 (1951) 5789-5791. 